Hector R. Wong

\title{
Personalized medicine, endotypes, and intensive care medicine
}

Received: 2 April 2015

Accepted: 7 April 2015

Published online: 24 April 2015

(C) Springer-Verlag Berlin Heidelberg and ESICM 2015

H. R. Wong (『)

Division of Critical Care Medicine, Cincinnati Children's Hospital Medical Center and Cincinnati Children's Research Foundation, Cincinnati, OH, USA

e-mail: hector.wong@cchmc.org

H. R. Wong

Department of Pediatrics, University of Cincinnati College of Medicine, Cincinnati, OH, USA

In his 2015 State of the Union Address, President Barack Obama announced the launching of a "Precision Medicine Initiative". The website hosting the White House Blog states, "The President's 2016 budget includes investments in an emerging field of medicine that takes into account individual differences in people's genes, microbiomes, environments, and lifestyles-making possible more effective, targeted treatments for diseases like cancer and diabetes" [1]. Subsequent to the address, Drs. Francis S. Collins and Harold Varmus [2] wrote an editorial enthusiastically supporting the initiative.

Precision medicine is conceptually identical to the paradigm of "personalized medicine". This emerging paradigm is focused on diagnostic testing, and how such testing can enable customization of medical therapies and interventions based on the unique molecular and biological characteristics of an individual patient. Currently, most efforts in the personalized medicine arena are focused on gene variants, and how those variants modify disease progression and response to treatment. In addition, the benefits of personalized medicine are often thought of in the context of oncology. Indeed, the Precision Medicine Initiative and the editorial by Drs. Collins and Varmus emphasize how knowledge surrounding gene variants can be applied to individualize oncologic therapy. While these are unquestionably appropriate areas of focus for personalized medicine with great potential, there are many other approaches to personalized medicine and many other fields of medicine amendable to this evolving paradigm.

The practice of intensive care medicine is in many ways ideally suited to a personalized medicine approach. For the most part, intensive care medicine physicians manage heterogeneous syndromes, rather than distinct disease nosologies. "Sepsis" embodies this concept well. As a syndrome, sepsis is highly heterogeneous at multiple levels [3]. As a syndrome caused by infection, the type of pathogen, the pathogen load, and the anatomic site of infection all contribute to sepsis heterogeneity. Beyond pathogen-related factors, there is also substantial heterogeneity with respect to the host response to infection. Further adding to this heterogeneity is the influence of existing comorbidities and developmental age. Finally, sepsis is characterized by a widely ranging baseline mortality risk, which becomes critically important for clinical decision-making and the conduct of clinical trials [4]. Other syndromes encountered in the intensive care unit are similarly characterized by multiple levels of heterogeneity.

Identifying individuals who are more or less responsive to a given therapeutic intervention is a fundamental tenet of personalized medicine. This is not foreign to intensive care medicine. In 2002, Annane and colleagues published a disruptive article in the field when they reported that patients with septic shock who did not respond to a corticotropin stimulation test had a survival advantage when treated with adjunctive hydrocortisone and fludrocortisone; whereas patients who did respond to the corticotropin stimulation test derived no benefit from 
adrenal hormone replacement therapy [5]. Although these findings were not replicated in a subsequent study [6] and corticotropin stimulation testing has fallen somewhat out of favor [7], the study by Annane and colleagues was nonetheless an important foray for intensive care medicine into the world of personalized medicine.

The field has also been active in identifying gene variants that impact the host inflammatory response, and may therefore identify the appropriate patients for immune-modulating therapies. For example, over 16 years ago, Mira and colleagues reported a single nucleotide polymorphism in the tumor necrosis factor- $\alpha$ promoter region that was independently associated with increased risk of mortality in patients with sepsis [8]. More recently, Meyer and colleagues reported on a coding variant of the interleukin-1 receptor antagonist (IL1RA) gene that is associated with increased plasma levels of IL1RA and decreased mortality in patients with acute respiratory distress syndrome or septic shock $[9,10]$. These findings are particularly germane given the availability of recombinant IL1RA for clinical use [11].

In this issue of Intensive Care Medicine, Knox and colleagues report on another approach to personalized medicine in patients with sepsis [12]. Using discoveryoriented computational methods centered on self-organizing maps and readily obtainable organ failure data, Knox and colleagues identified four clusters of patients with sepsis, defined by distinct combinations and burden of organ failure. After the clusters were identified, they found that cluster allocation is independently associated with outcomes. While one could argue that Knox and colleagues have identified surrogates for illness severity, the authors make a compelling case why this is not necessarily the case. In essence, the authors have elegantly demonstrated that not all sepsis or patterns of organ failure are the same, and that perhaps advanced computational methods are needed to dissect these important nuances.

Another way of viewing the work by Knox and colleagues is that they have identified "endotypes" of sepsis. An endotype is a subclass of a disease or syndrome, as defined by function or biology. In this case, Knox and colleagues identified sepsis endotypes based on organ failure patterns. In an analogous manner, another recent report identified endotypes of pediatric septic shock [13]. Based on a 100-gene expression signature and self-organizing maps, two broad endotypes of pediatric septic shock were derived and validated. Allocation to one of the two endotypes was independently associated with increased risk of mortality and increased organ failure burden. Importantly, the endotype-defining gene signature is enriched for genes corresponding to adaptive immunity and the glucocorticoid receptor signaling pathway, thus opening the way for identifying patients who may be more or less responsive to immune-enhancing therapies or adjunctive corticosteroids. Indeed, in a post hoc analysis the prescription of corticosteroids was associated with four times the risk of death in one of the two septic shock endotypes.

While the cluster-based endotypes identified by Knox and colleagues require validation, the study is nonetheless laudable in that it illustrates the need to pursue the concepts of personalized medicine in the intensive care unit. The major challenges for the field moving forward are to not only discover endotypes, but to also develop diagnostic tests that meet the time-sensitive demands of decision-making in the intensive care unit and to operationalize these tests to deliver more rational and appropriately targeted therapies for our critically ill patients [14].

\section{References}

1. Holst L (2015) The Precision Medicine Initiative: data-driven treatments as unique as your own body. https://www.whitehouse.gov/blog/2015/ 01/30/precision-medicine-initiativedata-driven-treatments-unique-yourown-body. Accessed 1 Apr 2015

2. Collins FS, Varmus H (2015) A new initiative on precision medicine. $\mathrm{N}$ Engl J Med 372:793-795

3. Marshall JC (2008) Sepsis: rethinking the approach to clinical research. J Leukoc Biol 83:471-482
4. Wong HR, Lindsell CJ, Pettila V, Meyer NJ, Thair SA, Karlsson S, Russell JA, Fjell CD, Boyd JH, Ruokonen E, Shashaty MG, Christie JD, Hart KW, Lahni P, Walley KR (2014) A multibiomarker-based outcome risk stratification model for adult septic shock. Crit Care Med 42:781-789

5. Annane D, Sebille V, Charpentier C, Bollaert PE, Francois B, Korach JM, Capellier G, Cohen Y, Azoulay E, Troche G, Chaumet-Riffaud P. Bellissant E (2002) Effect of treatment with low doses of hydrocortisone and fludrocortisone on mortality in patients with septic shock. JAMA 288:862-871
6. Sprung CL, Annane D, Keh D, Moreno R, Singer M, Freivogel K, Weiss YG, Benbenishty J, Kalenka A, Forst H, Laterre PF, Reinhart K, Cuthbertson BH, Payen D, Briegel J (2008) Hydrocortisone therapy for patients with septic shock. N Engl J Med 358:111-124

7. Dellinger RP, Levy MM, Rhodes A, Annane D, Gerlach H, Opal SM, Sevransky JE, Sprung CL, Douglas IS, Jaeschke R, Osborn TM, Nunnally ME, Townsend SR, Reinhart K, Kleinpell RM, Angus DC, Deutschman CS, Machado FR, Rubenfeld GD, Webb S, Beale RJ, Vincent JL, Moreno R (2013) Surviving sepsis campaign: international guidelines for management of severe sepsis and septic shock, 2012. Intensive Care Med 39:165-228 
8. Mira JP, Cariou A, Grall F, Delclaux C, 10. Meyer NJ, Ferguson JF, Feng R, Wang Losser MR, Heshmati F, Cheval C, Monchi M, Teboul JL, Riche F, Leleu G, Arbibe L, Mignon A, Delpech M, Dhainaut JF (1999) Association of TNF2, a TNF-alpha promoter polymorphism, with septic shock susceptibility and mortality: a multicenter study. JAMA 282:561-568

9. Meyer NJ, Feng R, Li M, Zhao Y, Sheu CC, Tejera P, Gallop R, Bellamy S, Rushefski M, Lanken PN, Aplenc R, O'Keefe GE, Wurfel MM, Christiani DC, Christie JD (2013) IL1RN coding variant is associated with lower risk of acute respiratory distress syndrome and increased plasma IL-1 receptor antagonist. Am J Respir Crit Care Med 187:950-959
F, Patel PN, Li M, Xue C, Qu L, Liu Y, Boyd JH, Russell JA, Christie JD, Walley KR, Reilly MP (2014) A functional synonymous coding variant in the IL1RN gene is associated with survival in septic shock. Am J Respir Crit Care Med 190:656-664

11. Dinarello CA, van der Meer JW (2013) Treating inflammation by blocking interleukin-1 in humans. Semin Immunol 25:469-484

12. Knox DB, Lanspa MJ, Kuttler KG, Brewer SC, Brown SM (2015)

Phenotypic clusters within sepsisassociated multiple organ dysfunction syndrome. Intensive Care Med. doi:10.1007/s00134-015-3764-7
13. Wong HR, Cvijanovich NZ, Anas N, Allen GL, Thomas NJ, Bigham MT, Weiss SL, Fitzgerald J, Checchia PA, Meyer K, Shanley TP, Quasney M, Hall M, Gedeit R, Freishtat RJ, Nowak J, Shekhar RS, Gertz S, Dawson E, Howard K, Harmon K, Beckman E, Frank E, Lindsell CJ (2015) Developing a clinically feasible personalized medicine approach to pediatric septic shock. Am J Respir Crit Care Med 191:309-315

14. Maslove DM, Wong HR (2014) Gene expression profiling in sepsis: timing, tissue, and translational considerations. Trends Mol Med 20:204-213 